this region without a pre-existing pilonidal sinus. In other sites infection or inflammation related to trauma is associated with the presence of a bursafor example, olecranon bursitis and the parapatellar bursitides-but there was no evidence in our cases of an adventitious bursa at operation. It would be interesting, however, to survey a sample of jazz ballet enthusiasts to see whether any have an uninfected bursa in this site.

Cases like those reported here are worth recognising, because in the absence of an underlying sinus the prognosis for full recovery without recurrence must be much better. Patients who are predisposed to infection should perhaps be advised against those exercises that result in trauma to the sacrococcygeal region.

We thank Mr W G Everett, consultant surgeon, for permission to report on his patients.

1 Clothier PR, Haywood IR. The natural history of the post anal (pilonidal) sinus. Ann $R$ Coll Surg Engl 1984;66:201-3.

2 Notaras MJ. A review of three popular methods of treatment of postanal (pilonidal) disease. $\mathrm{Br} \mathcal{F}$ Sung 1970;57:886-90.

3 Patey DH. A reappraisal of the acquired theory of sacrococcygeal pilonidal sinus and an assessment of its influence on surgical practice. Br $\mathcal{F}$ Surg 1969;56:463-6.

4 Buie LA. Jeep disease (pilonidal disease of mechanised warfare). Dis Colon Recuom 1982;25: 384-90.

(Accepted 26 August 1987)

Department of Surgery, Addenbrooke's Hospital, Cambridge CB1 $2 Q Q$

P J RADFORD, MA, BM, registrar in surgery

R A GREATOREX, MA, FRCS, senior registrar in surgery

Correspondence to: Dr Radford.

\section{Campylobacter pylori, gastritis, and peptic ulcer disease in central Africa}

Peptic ulcer disease and gastritis are common medical problems in Rwandese patients. Among 3040 patients referred to the endoscopy clinic of the Centre Hospitalier de Kigali between April 1981 and April 1986, almost $900(29 \%)$ had active duodenal ulcer and over $2550(84 \%)$ various degrees of gastritis (unpublished). Recently a correlation has been reported between the presence of Campylobacter pylori in gastric mucosa and peptic ulcer disease. ${ }^{1}$ The aim of this prospective study was to discover the prevalence of $C$ pylori among Rwandese patients.

\section{Patients, methods, and results}

During May and June 1986, 184 upper digestive fibroscopies were performed in 173 patients with dyspepsia (94 women (mean age 34.3), 79 men (mean age $35.0)$ ) and the following appearances recorded: duodenal ulcer (43 cases), healed duodenal ulcer (6), gastric ulcer (2), gastritis (90), neoplastic disease (7), normal (25). Eleven patients with duodenal ulcer had repeat endoscopy with antral biopsy for culture of $C$ pylori after six weeks' treatment with ranitidine. Two antral samples and one fundal biopsy sample were taken from 166 patients. One antral and the fundal sample were submitted in $10 \%$ formaldehyde solution for histopathology. All sections were stained with haematoxylin and eosin and samples from 17 patients by the Warthin-Starry technique. Gastritis was graded as superficial if the infiltrate was limited to the upper layer of the lamina propria and global if the lamina propria was entirely invaded. The pattern of inflammation was graded 1 to 6 according to its activity (linked to the presence of polymorph infiltration) and severity. Lymphocytic gastritis, recently described as a histological entity, ${ }^{2}$ is characterised by massive lymphocytic infiltration of the epithelium. Antral biopsy samples for microbiology were crushed between two sterile slides. One slide was examined after staining with $1 \%$ gentian violet solution. The tissue fragment adhering to the other slide was plated on to Skirrow's medium ${ }^{3}$ and incubated for seven days at $37^{\circ} \mathrm{C}$ in an anaerobic jar containing a Gas-Pak without catalyst. All 20 isolates examined in Belgium were confirmed as $C$ pylori. Among the seven patients with neoplasm only one biopsy sample was sent for microbiology, the others being used for diagnosis of the tumorous process.

A total of 131 patients were infected with $C$ pylori with no difference in prevalence between men and women. They included all patients with duodenal ulcer, 67 of the $90(74 \%)$ with an endoscopic diagnosis of gastritis $(52$ of the 72 ( $72 \%$ ) with mucosal oedema, 15 of the $18(83 \%)$ with atrophy), three of the seven with neoplasm, and 12 of the $25(48 \%)$ with endoscopically normal gastric mucosa (table). Various degrees of gastritis were present in all patients with adequate biopsy samples. $C$ pylori was isolated from 18 of the $39(46 \%)$ with quiescent gastritis and from 95 of the $99(96 \%)$ with active gastritis. Active gastritis was present mainly in groups with the highest level of infection: in 29 out of $39(74 \%)$ patients with duodenal ulcer, 43 out of $64(67 \%)$ with mucosal oedema, and 13 out of $15(87 \%)$ with atrophy, a lower level being found in the "normal" group (10 out of $19 ; 53 \%$ ). Repeat endoscopy in the 11 patients with duodenal ulcer disclosed complete healing of ulcer, though nine remained infected. There was a strong correlation between the results of culture and direct visualisation after staining with gentian violet or by the Warthin-Starry technique.

\section{Comment}

This study disclosed a high level $(75 \cdot 5 \%)$ of $C$ pylori gastric infection in Rwandese patients and a close relation with duodenal ulcer and active gastritis. The clinical significance of the organism remains to be elucidated. This study on $C$ pylori, the first from central Africa, suggests a widespread prevalence of the organism, similar results having been reported from other continents. $^{45}$

We thank Professor J P Butzler (Hôpital St Pierre, Brussels) for confirming the strains and Mrs A Roobrouck and P Uwamaria for their help.

1 Marshall BJ, Warren JR. Unidentified curved bacili in the stomach of patients with gastritis and peptic ulceration. Lancet 1984;i:1311-4.

2 Haot J, Delos M, Wallez L, Hardy N, Lenzen B, Jouret-Mourin A. Les lymphocytes intraépithéliaux en pathologie gastrique inflammatoire. Acta Endoscopica 1986;16:61.

3 Lennette EH, Balows A, Hausler WJ, Shadomy HJ. Manual of clinical microbiology. 4th ed. Washington: American Society for Microbiology, 1985:1083.

4 Ishii E, Inoue $\mathrm{H}$, Tsuyuguchi T, et al. Campylobacter-like organisms in cases of stomach diseases in Japan. In: Pearson AD, Skirrow MB, Lior H, Rowe B, eds. Campylobacter III: proceedings of the third international workshop on campylobacter infections. London: Public Health Laboratory Service, 1985:179.

5 Tytgat GNJ, Langenberg ML, Rauws E, Rietra PTGM, Campylobacter-like organisms (CLO) in the human stomach. Gastroenterology 1985;88:1620(Abstract).

(Accepted 12 fune 1987)

Centre Hospitalier de Kigali, Rwanda

D ROUVROY, MD, consultant internist

J BOGAERTS, MD, consultant microbiologist

ONSENGIUMWA, MD, fellow in internal medicine

M OMAR, MD, fellow in internal medicine

Centre Diagnostic Leo Chevalier, Tournai, Belgium

L VERSAILLES, MD, consultant pathologist

Cliniques Universitaires St Luc, Brussels, Belgium

J HAOT, MD, professor of pathology

Correspondence to: Dr D Rouvroy, BP 675 Kigali, Rwanda, Central Africa.

Histopathology in diagnostic groups and numbers of patients from whom $C$ pylori was cultured (figures in parentheses)

\begin{tabular}{|c|c|c|c|c|c|c|c|c|}
\hline & \multirow{2}{*}{$\begin{array}{c}\text { Grade of } \\
\text { inflammation }\end{array}$} & \multirow{2}{*}{$\begin{array}{l}\text { Duodenal } \\
\text { ulcer }\end{array}$} & \multirow{2}{*}{$\begin{array}{l}\text { Healed } \\
\text { duodenal } \\
\text { ulcer }\end{array}$} & \multirow{2}{*}{$\begin{array}{l}\text { Gastric } \\
\text { ulcer }\end{array}$} & \multicolumn{2}{|c|}{ Gastritis } & \multirow[b]{2}{*}{ Normal } & \multirow[b]{2}{*}{ Total } \\
\hline & & & & & Oedema & Atrophy & & \\
\hline Quiescent gastritis & $S 1$ & & $2(1)$ & & $1(0)$ & $2(1)$ & $1(0)$ & $6(2 ; 33 \%)$ \\
\hline Active gastritis & S 3 & & & & & & $1(1)$ & $1(1)$ \\
\hline \multirow{2}{*}{ Quiescent gastritis } & G 1 & $8(8)$ & $3(2)$ & $1(1)$ & $14(4)$ & & $7(1)$ & $33(16 ; 48 \%)$ \\
\hline & 3 & $20(20)$ & $1(1)$ & $1(1)$ & $35(33)$ & $7(6)$ & $6(5)$ & $70(66 ; 94 \%)$ \\
\hline \multirow[t]{2}{*}{ Active gastritis } & 4 & $9(9)$ & & & $10(10)$ & $4(4)$ & $3(3)$ & $26(26 ; 100 \%)$ \\
\hline & $\begin{array}{l}5 \\
6\end{array}$ & & & & & $\begin{array}{l}1(1) \\
1(1)\end{array}$ & & $\begin{array}{l}1(1) \\
1(1)\end{array}$ \\
\hline Lymphocytic gastritis & & $2(2)$ & & & $4(3)$ & & $1(0)$ & $7(5 ; 71 \%)$ \\
\hline Inadequate & & $4(4)$ & & & $8(2)$ & $3(2)$ & $6(2)$ & $21(10 ; 48 \%)$ \\
\hline Total & & $43(43)$ & $6(4)$ & $2(2)$ & $72(52)$ & $18(15)$ & $25(12)$ & $166(128 ; 77 \%)$ \\
\hline
\end{tabular}

$\star S=$ Superficial. $\mathbf{G}=$ Global. 